\author{
Przeglad SejMOWY \\ nr 5(160)/2020, s. 113-132; https://doi.org/10.31268/PS.2020.68 \\ OKTAWIAN NAWROT* \\ VALERI VACHEV**
}

\title{
O standardach oceny kandydatów do pełnienia urzędu sędziego przez Krajową Radę Sądownictwa
}

Rozpatrywanie i ocena kandydatów do pełnienia urzędu sędziego, a następnie przedstawianie Prezydentowi Rzeczypospolitej Polskiej wniosków o powołanie sędziów stanowią jedne z najistotniejszych kompetencji Krajowej Rady Sądownictwa. Standard tej oceny zasadniczo wyznaczony został przez normy konstytucyjne oraz przepisy ustawy o Krajowej Radzie Sądownictwa. Zgodnie z nimi ocena powinna być dokonywana w oparciu o przejrzyste, jednolite i sprawiedliwe kryteria selekcyjne. Konsekwentnie ocena dokonywana przez Krajową Radę Sądownictwa powinna odpowiadać określonemu standardowi metodologicznemu. Celem opracowania jest określenie konstytucyjnego i ustawowego standardu metodologicznego ocen kandydatów do pełnienia urzędu sędziego dokonywanych przez Krajową Radę Sądownictwa.

SŁowa KLuCzowe: Krajowa Rada Sądownictwa, kandydat na urząd sędziego, ocena kandydata na urząd sędziego, powołanie na urząd sędziego, odwołanie od uchwały KRS

\section{On standards of evaluation of candidates for the office of judge by the National Council of the Judiciary}

Consideration and evaluation of candidates for the office of judge, and then presentation to the President of the Republic of Poland of applications for the appointment of judges are among the most important competences of the National Council of the Judiciary. The standard of this assessment has essentially been set by constitutional standards and the provisions of the Act on the National Council of the Judiciary. According to these standards and provisions, the assessment should be based on transparent, uniform and fair selection criteria. Consequently, the assessment carried out by the National Council of the Judiciary should meet a specific methodological standard. The aim of the study is to define a constitutional and statutory methodological standard for the assessment of candidates for the office of judge by the National Council of the Judiciary.

KEY WORDS: National Council of the Judiciary, candidate for the office of judge, evaluation of a candidate for the office of judge, appointment to the office of judge, appeal against the resolution of the National Council of the Judiciary

* Dr hab. Oktawian Nawrot, profesor Uniwersytetu Gdańskiego, Wydział Prawa i Administracji, oktawian.nawrot@ug.edu.pl, https://orcid.org/0000-0002-9345-1198

** Dr Valeri Vachev, Uniwersytet Warszawski, Wydział Prawa i Administracji, vv@wpia.uw.edu.pl,https://orcid.org/0000-0001-6778-0900 


\section{Wprowadzenie}

Rozpatrywanie i ocena kandydatów do pełnienia urzędu sędziego, a następnie przedstawianie Prezydentowi Rzeczypospolitej Polskiej wniosków o powołanie sędziów stanowią jedne z najistotniejszych kompetencji Krajowej Rady Sądownictwa ${ }^{1}$. Są one immanentnie powiązane z konstytucyjnym obowiązkiem Rady trwania na straży niezależności sądów i niezawisłości sędziów określonym w art. 186 ust. 1 ustawy zasadniczej. W związku z powyższym można by rzec, że obowiązki te są wpisane w istotę Krajowej Rady Sądownictwa. Konsekwentnie należy stwierdzić, że wskazane kompetencje mają istotne znaczenie z perspektywy zasad ustrojowych — za ich pomocą Krajowa Rada Sądownictwa powinna bowiem wzmacniać gwarancje zasady trójpodziału władzy. Jednocześnie kompetencje KRS służyć muszą urzeczywistnieniu jednego z podstawowych praw człowieka, a mianowicie gwarantowanego $\mathrm{w}$ art. 45 Konstytucji RP prawa do sądu².

\section{Postępowanie przed KRS}

Zgodnie $\mathrm{z}$ art. 33 ust. 1 ustawy o KRS w sprawach indywidualnych Rada podejmuje uchwały po wszechstronnym rozważeniu sprawy na podstawie udostępnionej dokumentacji oraz wyjaśnień uczestników postępowania lub innych osób, jeżeli zostały złożone. W sytuacji gdy na stanowisko sędziowskie zgłosił się więcej niż jeden kandydat, poszczególne kandydatury w pierwszej kolejności rozpatrywane są przez zespół Rady zgodnie z art. 35 ust. 2 ustawy o KRS. Zespół, ustalając kolejność kandydatów na liście, kieruje się więc przede wszystkim oceną kwalifikacji kandydatów, a ponadto uwzględnia doświadczenie zawodowe, w tym doświadczenie w stosowaniu przepisów prawa, dorobek naukowy, opinie przełożonych, rekomendacje, publikacje i inne dokumenty dołączone do karty zgłoszenia, a także opinię kolegium właściwego sądu oraz ocenę właściwego zgromadzenia ogólnego sędziów.

Następnie, zgodnie z art. 37 ust. 1 ustawy o KRS, Rada rozpatruje i ocenia na posiedzeniu wszystkie zgłoszone kandydatury łącznie. W trakcie posiedzenia członkowie zespołu, będący referentami sprawy, w sposób zwięzły przedstawiają stan (ze szczególnym podkreśleniem okoliczności istotnych do podjęcia przez KRS uchwały) i stanowisko zespołu, a ponadto udzielają odpowiedzi na pytania członków Rady dotyczące danej sprawy ${ }^{3}$.

${ }^{1}$ Art. 179 Konstytucji Rzeczypospolitej Polskiej z dnia 2 kwietnia 1997 r. (Dz.U. nr 78, poz. 483, ze zm.) oraz art. 3 ust. 1 pkt 1 i 2 ustawy z dnia 12 maja 2011 r. o Krajowej Radzie Sądownictwa (tekst jedn. Dz.U. z 2019 r. poz. 84, ze zm. [dalej: ustawa o KRS]).

${ }^{2}$ Szerzej: K. Szczucki, Komentarz do art. 186 Konstytucji RP, [w:] Konstytucja RP, t. 2: Komentarz. Art. 87-243, red. M. Safjan, L. Bosek, Warszawa 2016, s. 1112-1119.

${ }_{3}^{3}$ M. Niezgódka-Medek, Komentarz do art. 33 ustawy o Krajowej Radzie Sadownictwa, [w:] M. Niezgódka-Medek, R. Pęk, Krajowa Rada Sąownictwa. Komentarz, Warszawa 2013, pkt 3. 
Podejmując uchwałę obejmującą rozstrzygnięcia w przedmiocie przedstawienia wniosku o powołanie do pełnienia urzędu sędziego w stosunku do wszystkich kandydatów, Rada nie jest związana stanowiskiem zespołu i może odmiennie aniżeli zespół ocenić poszczególne kandydatury na podstawie przyjętych kryteriów. Każdorazowo jednak Rada, stosownie do wspomnianego wyżej obowiązku wszechstronnego rozważenia sprawy, zobligowana jest do wzięcia pod uwagę przygotowanej przez zespół listy rekomendowanych kandydatów ${ }^{4}$.

Zgodnie z art. 42 ust. 1 ustawy o KRS uchwały Rady w sprawach indywidualnych, a zatem także uchwały dotyczące przedstawienia lub odmowy przedstawienia Prezydentowi RP wniosku o powołanie do pełnienia urzędu sędziego, wymagają uzasadnienia, które sporządza się w terminie miesiąca od ich podjęcia (art. 42 ust. 2 ustawy o KRS). Jak wielokrotnie podkreślał Sąd Najwyższy, art. 42 ust. 1 ustawy o KRS nie wskazuje bezpośrednio wymogów, które powinno spełniać uzasadnienie uchwały 5 . Zgodnie z orzecznictwem Sądu Najwyższego do naruszenia przywołanego przepisu może więc dojść w sytuacji, gdy uchwała nie zawiera uzasadnienia bądź treść uzasadnienia uniemożliwia sądową kontrolę zgodności zaskarżonej uchwały z prawem ${ }^{6}$. Uchwały $w$ sprawach indywidualnych doręcza się uczestnikom postępowania wraz z rzeczonym uzasadnieniem i pouczeniem o sposobie wniesienia odwołania do Sądu Najwyższego (art. 42 ust. 3 ustawy o KRS).

Na marginesie należy przypomnieć, że do $2001 \mathrm{r}$. uchwały KRS uznawane były za decyzje administracyjne i tym samym odwołania od nich rozpatrywane były przez Naczelny Sąd Administracyjny ${ }^{7}$. Przyjmowano bowiem, że Krajowa Rada Sądownictwa nie wydaje sędziom poleceń służbowych i nie ma wobec nich uprawnień o charakterze nadzoru służbowego ${ }^{8}$. W konsekwencji w pierwotnym okresie funkcjonowania KRS judykatura stanowczo podkreślała konieczność przestrzegania przez Radę standardów obowiązujących w postępowaniu administracyjnym9. Dopiero ustawą z dnia 27 lipca 2001 r. o Krajowej Radzie Sądownictwa ${ }^{10}$ przyznała kompetencję do rozpatrywania odwołań od uchwał KRS w sprawach indywidualnych Sądowi Najwyższemu (art. 13

4 Wyrok SN z 26 kwietnia 2012 r., sygn. akt III KRS 12/12.

5 Vide m.in. wyrok SN z 12 czerwca 2012 r., sygn. akt III KRS 15/12; wyrok SN z 4 lipca 2012 r., sygn. akt III KRS 16/12; wyrok SN z 13 listopada 2012 r., sygn. akt III KRS 32/12; wyrok SN z 22 listopada 2013 r., sygn. akt III KRS 226/13.

${ }^{6}$ Wyrok SN z 22 listopada 2013 r., sygn. akt III KRS 226/13. Vide również wyrok SN z 17 sierpnia 2010 r., sygn. akt III KRS 10/10; wyrok SN z 5 sierpnia 2011 r., sygn. akt III KRS 9/11; wyrok SN z 15 stycznia 2013 r., sygn. akt III KRS 33/12; wyrok SN z 12 czerwca 2019 r., sygn. akt I NO 38/19.

7 Tak NSA w wyroku z 22 kwietnia 1993 r.: „Uchwała Krajowej Rady Sądownictwa podjęta na podstawie art. 2 pkt 4 ustawy z 20 grudnia 1989 r. w sprawie odmowy wyrażenia zgody na dalsze zajmowanie stanowiska przez sędziego, który ukończył 65 lat życia, ma charakter decyzji administracyjnej i może być przez sędziego zaskarżona do Naczelnego Sądu Administracyjnego" (sygn. akt II SA 2577/92).

8 Vide uchwała składu siedmiu sędziów Sądu Najwyższego z dnia 21 grudnia 1993 r., sygn. akt III AZP 20/93.

9 Vide wyrok NSA z 27 kwietnia 1995 r., sygn. akt II SA 631/95.

10 Dz.U. nr 100, poz. 1082. 
ust. 2 tejże ustawy). Przypomnieć należy, że przepis ten został uznany przez Trybunał Konstytucyjny za niezgodny z ustawą zasadniczą w zakresie, w jakim wyłączał pierwotnie możliwość odwołania się od uchwały KRS w przedmiocie kierowanego do Prezydenta RP wniosku o powołanie sędziego ${ }^{11}$.

\section{Postępowanie przed Sądem Najwyższym}

W obecnym stanie prawnym uczestnik postępowania może odwołać się do Sądu Najwyższego z powodu sprzeczności uchwały Rady z prawem, o ile przepisy odrębne nie stanowią inaczej (art. 44 ust. 1 zd. 1 ustawy o KRS). Zgodnie z art. 44 ust. 3 ustawy o KRS do postępowania przed Sądem Najwyższym w sprawach z odwołań od uchwał Rady stosuje się przepisy ustawy z dnia 17 listopada 1964 r. - Kodeks postępowania cywilnego ${ }^{12}$ o skardze kasacyjnej, z wyłączeniem przepisu art. $87^{1}$ ustanawiającego tzw. przymus adwokacko-radcowski w postępowaniu przed SN.

Odesłanie do przepisów Kodeksu postępowania cywilnego o skardze kasacyjnej determinuje sposób wyznaczenia granic rozpoznania przez Sąd Najwyższy sprawy zainicjowanej odwołaniem uczestnika postępowania. Zgodnie zaś z art. $398^{13} \S 1$ k.p.c. Sąd Najwyższy rozpoznaje skargę kasacyjną w granicach zaskarżenia oraz w granicach podstaw $^{13}$, w przeciwieństwie do postępowania apelacyjnego w postępowaniu kasacyjnym Sąd Najwyższy nie rozpoznaje bowiem sprawy, lecz jedynie skargę kasacyjną. Pozostaje tym samym związany nie tylko granicami zaskarżenia, lecz także podstawami kasacyjnymi wskazanymi przez skarżącego ${ }^{14}$. Wyjątek uprawniający Sąd Najwyższy do wyjścia poza granice skargi kasacyjnej stanowi obowiązek uwzględnienia (ex officio) zachodzącej nieważności postępowania przed sądem II instancji ${ }^{15}$.

Zgodnie z treścią przywoływanego już art. 44 ust. 1 ustawy o KRS w sprawach z odwołań od uchwał Rady dotyczących obsady stanowisk sędziowskich kognicja Sądu Najwyższego obejmuje wyłącznie badanie, czy uchwała nie pozostaje w sprzeczności z prawem. Według utrwalonego orzecznictwa oznacza to, że Sąd Najwyższy nie ma kompetencji do merytorycznego rozpatrywania kandydata na sędziego, a tym bardziej jego kontrkandydatów ${ }^{16}$. Przeciwny pogląd prowadziłby wprost do podważenia konstytucyjnych kompetencji Rady.

11 Vide wyrok TK z 27 maja 2008 r., sygn. akt SK 57/06.

${ }_{12}$ Dz.U. nr 43, poz. 296, ze zm. [dalej: k.p.c.].

13 Vide szerzej M. Michalska, Zakres rozpoznania sprawy przed Sądem Najwyższym w postępowaniu cywilnym, „Państwo i Prawo” 2003, nr 10, s. 70.

${ }^{14}$ M. Manowska, Komentarz do art. $398^{13}$ k.p.c., [w:] Kodeks postępowania cywilnego. Komentarz, t. 1, red. M. Manowska, Warszawa 2015, s. 1027.

${ }_{15}$ Vide J. Gudowski, Skarga kasacyjna, [w:] System prawa procesowego cywilnego. Środki zaskarżenia, t. 3, cz. 2, red. J. Gudowski, Warszawa 2013, s. 1040 i wskazane tam orzecznictwo Sądu Najwyższego. Z najnowszego orzecznictwa Sądu Najwyższego vide wyrok SN z 7 marca 2019 r., sygn. akt I NO 1/19.

16 Vide np. wyrok SN z 13 listopada... 
Brak kognicji Sądu Najwyższego do merytorycznego rozpatrywania kandydatów nie oznacza jednakże, że sposób dokonania oceny kandydatów przez KRS nie podlega sądowej kontroli. Przeciwnie, przedmiot postępowania w kwestii oceny postępowania i przedstawienia wniosku o jego powołanie na stanowisko sędziego ma charakter sprawy w rozumieniu art. 41 ust. 1 Konstytucji RP, a tym samym podlega kontroli sądowej w zakresie właściwym tego rodzaju sprawom ${ }^{17}$. W szczególności kontroli sądowej podlega wynikające z art. 60 Konstytucji RP prawo dostępu do służby publicznej na jednakowych zasadach ${ }^{18}$, co w konsekwencji oznacza, że kognicja Sądu Najwyższego obejmuje badanie, czy Rada przestrzegała w postępowaniu przejrzystych, jednolitych i sprawiedliwych kryteriów selekcyjnych w odniesieniu do wszystkich uczestników procedury nominacyjnej ${ }^{19}$. Obok zgodności z prawem kontrola obejmuje więc poprawność zastosowania przyjętych przez Radę kryteriów, w szczególności w warstwie metodologicznej. Poprawne i konsekwentne zastosowanie przyjętych kryteriów nie tylko bowiem przekłada się na rekomendację kandydatów spełniających określone warunki lub spełniających je w stopniu wyższym aniżeli pozostali kandydaci, ale także stanowi warunek sine qua non przeprowadzenia pierwszej części postępowania nominacyjnego w sposób odpowiadający standardowi konstytucyjnemu wynikającemu z art. 60 Konstytucji RP.

Mówiąc o poprawności metodologicznej, mamy na myśli poprawność czynności wykonywanych przez Radę w procesie oceny kandydatów, która przekłada się na wymiar eksplanacyjny uchwały, czyli treść jej uzasadnienia. Ocenie z tego punktu widzenia podlegać więc będzie uzasadnienie uchwały w warstwie zarówno typowo deskryptywnej, jak i uzasadnienia konkretnej decyzji, przy czym warstwy te mogą do pewnego stopnia pozostawać względem siebie w relacji krzyżowania się. Zauważyć przy tym należy, że ocena poprawności dotyczyć będzie zabiegów poznawczych stanowiących domenę metodologii ogólnej, czyli tych typów zabiegów poznawczych, które są wspólne wszystkim naukom, w szczególności wnioskowania, podziału logicznego i klasyfikacji ${ }^{20}$. Nie istnieją bowiem normy prawne pełniące w tym zakresie funkcję swoistego metodologicznego lex specialis, które marginalizowałyby znaczenie wskazanych typów zabiegów poznawczych. Na marginesie należy zauważyć, że immanentne powiązanie oceny pierwszej części procedury nominacyjnej z konstytucyjnym prawem dostępu do służby publicznej na jednakowych zasadach czyniłoby taką konstrukcję wysoce kontrowersyjną, zwłaszcza jeśli wprowadzona zostałaby na poziomie aktów wykonawczych.

17 Ibidem.

18 Szerzej na temat konstytucyjnego prawa dostępu do służby publicznej vide M. Florczak-Wątor, Komentarz do art. 60 Konstytucji RP, [w:] Konstytucja RP, t. 1: Komentarz. Art. 1-86, red. M. Safjan, L. Bosek, Warszawa 2016, s. 1403-1420 i przytoczona tam literatura.

19 Vide np. wyrok SN z 13 lipca 2017 r., sygn. akt III KRS 17/17.

${ }^{20}$ Confer K. Ajdukiewicz, Logika pragmatyczna, Warszawa 1975, s. 173-177; F. Gołba, P. Piękoś, P. Turkowski, Logika dla prawników. Wykłady. Ćwiczenia. Zadania, Warszawa 2012, s. 168-177; Mała encyklopedia logiki, red. W. Marciszewski, Wrocław-Warszawa-Kraków-Gdańsk-Łódź 1988, s. 123-128; O. Nawrot, Wprowadzenie do logiki dla prawników, Warszawa 2017, s. 18, 105-112, 261-285; Z. Ziembiński, Logika praktyczna, Warszawa 1995, s. 10-11. 


\section{Liczba rekomendowanych przez KRS kandydatów}

Przed rozważaniami dotyczącymi standardów metodologicznych uzasadnienia uchwały KRS w przedmiocie przedstawienia wniosku o powołanie do pełnienia urzędu sędziego zauważyć należy, że w związku z prowadzonym postępowaniem konkursowym Krajowa Rada Sądownictwa ma możliwość:

1) nierekomendowania żadnego $\mathrm{z}$ kandydatów,

2) rekomendowania kandydatów na część wolnych stanowisk,

3) rekomendowania kandydatów w liczbie odpowiadającej liczbie wolnych stanowisk,

4) rekomendowania kandydatów w liczbie przekraczającej liczbę wolnych stanowisk.

\section{Kompetencje Prezydenta i KRS w zakresie powoływania na urząd sędziego}

Jak już zasygnalizowano, powoływanie danej osoby do pełnienia urzędu sędziego stanowi prerogatywę Prezydenta (art. 144 ust. 3 pkt 17 Konstytucji RP), przy czym wyłączną zdolność postulacyjną w tym zakresie posiada Krajowa Rada Sądownictwa (art. 179 Konstytucji RP) ${ }^{21}$. Obowiązujący w Polsce nominacyjny model powoływania na stanowisko sędziowskie wymaga zatem współdziałania dwóch wskazanych organów konstytucyjnych. Konsekwentnie nie istnieje możliwość samodzielnego, skutecznego i pełnego działania któregokolwiek z wymienionych organów skutkującego powołaniem kandydata na urząd sędziego. Ich kompetencje we wskazanym zakresie dopełniają się ${ }^{22}$. W tym kontekście w literaturze przyjmuje się, że akt nominacyjny Prezydenta nie ma charakteru swobodnego (Prezydent nie może powołać dowolnej osoby), lecz jest to system ograniczony (Prezydent może nominować jedynie osobę wskazaną przez Radę) ${ }^{23}$.

Wniosek Krajowej Rady Sądownictwa stanowi nie tylko warunek sine qua non uruchomienia kompetencji Prezydenta do powołania kandydata na urząd sędziego, ma on bowiem charakter konstytutywny — bez niego kompetencja Prezydenta nie ulega aktualizacji w związku z prowadzonym postępowaniem nominacyjnym. W ten sposób

${ }^{21}$ Vide T. Ereciński, J. Gudowski, J. Iwulski, Komentarz do art. 55 u.p.u.s.p., [w:] Prawo o ustroju sądów powszechnych, red. J. Gudowski, Warszawa 2009, s. 186.

${ }_{22}$ Vide iidem, Komentarz do prawa o ustroju sadów powszechnych i ustawy o Krajowej Radzie Sadownictwa, Warszawa 2002, s. 146; M. Masternak-Kubiak, Komentarz do art. 179 Konstytucji Rzeczypospolitej Polskiej, [w:] Konstytucja Rzeczypospolitej Polskiej. Komentarz, red. M. Haczkowska, Warszawa 2014, <https://sip.lex.pl/\#/commentary/587599166/396606>, dostęp 28 VIII 2019; K. Weitz, Komentarz do art. 179 Konstytucji RP, [w:] Konstytucja RP, t. 2: Komentarz. Art. 87-243, red. M. Safjan, L. Bosek, Warszawa 2016, s. 1041; postanowienie TK z 3 czerwca 2008 r., sygn. akt Kpt 1/08; wyrok TK z 8 maja 2012 r., sygn. akt K 7/10; wyrok TK z 5 czerwca 2012 r., sygn. akt K 18/09.

${ }^{23}$ K. Weitz, op. cit., s. 1041. 
zabezpieczona zostaje równowaga pomiędzy władzą Prezydenta a niezależnością sądów i niezawisłością sędziów ${ }^{24}$.

Z powyższego jednoznacznie wynika, że Krajowa Rada Sądownictwa posiada samodzielną konstytucyjną kompetencję w zakresie występowania z wnioskiem o powołanie na urząd sędziego. Nie oznacza to jednak, że Rada nie pozostaje związana ustawowo określonymi kryteriami oceniania kandydatów i wymaganiami ustanowionymi w ustawach dotyczących poszczególnych rodzajów sądów. Przeciwnie, co do zasady stanowią one wyłączne podstawy do podejmowania uchwał w przedmiocie powołania na stanowisko sędziego.

Kompetencja Prezydenta określona w art. 144 ust. 3 pkt 17 Konstytucji RP ma charakter prerogatywy. Tym samym akt urzędowy Prezydenta powołania na urząd sędziego nie wymaga kontrasygnaty Prezesa Rady Ministrów ${ }^{25}$. Przyjęte przez ustrojodawcę rozwiązanie ponownie służyć ma ochronie niezależności władzy sądowniczej i niezawisłości sędziowskiej. Charakter prawny kompetencji w zakresie powoływania sędziów przekłada się na dominujący w doktrynie i wyrażany w orzecznictwie Sądu Najwyższego pogląd o możliwości nieuwzględnienia przez Prezydenta wniosku Krajowej Rady Sądownictwa o powołanie na urząd sędziego. Kompetencja Prezydenta przewidziana w art. 144 ust. 3 pkt 17 Konstytucji RP ma bowiem charakter wład$\mathrm{czy}^{26}$. W tym kontekście rozważane jest również zagadnienie dotyczące możliwości niepowołania przez Prezydenta żadnego z rekomendowanych przez Radę kandydatów. Jak się wydaje, możliwość ta, w ramach prerogatywy Prezydenta, potwierdzona została przez Trybunał Konstytucyjny w postanowieniu z dnia 23 czerwca 2008 r. ${ }^{27}$ : „W sensie prakseologicznym, każdy z tych aktów [Rady i Prezydenta — przyp. O.N. i V.V.] poprzedzony jest pewną racjonalizacją (w procesie decyzyjnym), która [...] uzewnętrznia się $[\ldots] \mathrm{w}$ wypadku Prezydenta - w postaci postanowienia w sprawie skorzystania (lub nieskorzystania) z kompetencji powołania na urząd sędziego".

$\mathrm{W}$ podobnym tonie wypowiedział się również m.in. sędzia Piotr Tuleja w szerokim uzasadnieniu do zdania odrębnego do postanowienia TK z 19 czerwca 2012 r.: „stanowisko to potwierdza ujęcie uprawnienia nominacyjnego Prezydenta właśnie w formę prerogatywy, albowiem [...] nie ma on prawnego obowiązku uwzględnienia wniosku Rady, a akt powołania nie sprowadza się wyłącznie do potwierdzenia decyzji podjętej przez inny konstytucyjny organ państwa. Uwzględniając postanowienie art. 126 ust. 1 i 2 Konstytucji RP, Prezydent Rzeczypospolitej przy wykonywaniu

24 Ibidem, s. 1043.

25 Vide T. Ereciński, J. Gudowski, J. Iwulski, Komentarz do art. 55..., s. 186.

${ }^{26}$ L. Garlicki, Komentarz do art. 179, [w:] Konstytucja Rzeczypospolitej Polskiej. Komentarz, t. 4, red. L. Garlicki, Warszawa 2005, s. 5 i n.; T. Ereciński, J. Gudowski, J. Iwulski, Komentarz do art. 55..., s. 187; K. Szczucki, Ustawa o Sądzie Najwyższym. Komentarz, Warszawa 2018, s. 216. Odmiennie vide J. Ciapała, Charakter kompetencji Prezydenta RP. Uwagi w kontekście kompetencji w zakresie powoływania sędziów, „Przegląd Sejmowy” 2008, nr 4, s. 38; R. Glajcar, Instytucja Prezydenta w Polsce, Czechach i Stowacji w latach 1989-2000, Toruń 2005, s. 259.

27 Sygn. akt Kpt 1/08. 
swoich konstytucyjnych i ustawowych zadań symbolizuje majestat państwa. Dodatkowo podkreślenia wymaga, że kompetencja powoływania sędziów przez głowę państwa ujmowana jest jako jeden z przejawów wzajemnego oddziaływania i hamowania władz. Wprawdzie brak funktora modalnego («może») w art. 179 Konstytucji RP sugerować mógłby prima facie, że przepis ten zawiera normę obligującą adresata do wydania aktu nominacyjnego ${ }^{28}$. Jednakże użycie we wskazanym przepisie ustawy zasadniczej sformułowania «na wniosek» wskazuje na niewiążący Prezydenta charakter wystąpienia Krajowej Rady Sądownictwa. Gdyby bowiem ustrojodawca chciał pozbawić głowę państwa pewnej swobody decyzyjnej w przedmiocie nominacji sędziowskich, posłużyłby się wówczas innym sformułowaniem: wyłączającym już na etapie wykładni językowej wątpliwości interpretacyjne, ewentualnie - wskazałby (dookreśliłby) w ramach kolejnego zdania lub ustępu art. 179 ustawy zasadniczej na związanie Prezydenta pozytywnym stanowiskiem KRS wobec kandydata na sędziego. [...] Z tych też powodów znajduje swoje oparcie w obecnym stanie konstytucyjnym akt urzędowy Prezydenta Rzeczypospolitej w przedmiocie odmowy powołania do pełnienia urzędu na stanowisku sędziego. Nadanie temu aktowi charakteru prerogatywy służy wzmocnieniu niezależności sądów i niezawisłości sędziów od czynnika politycznego"29.

Już w latach dziewięćdziesiątych ubiegłego stulecia w literaturze sformułowano pogląd, że akceptacja stanowiska, jakoby Prezydent był obowiązany do uwzględnienia wniosku KRS, oznacza w gruncie rzeczy istotne ograniczenie konstytucyjnych kompetencji głowy państwa ${ }^{30}$. Przyjmowano w związku z tym, że Prezydent może albo uwzględnić, albo odrzucić wniosek KRS. Krytycznie natomiast oceniano brak ustosunkowania się przez Prezydenta do wniosku Rady ${ }^{31}$. Stanowisko to pozostaje aktualne także w najnowszych wypowiedziach komentatorów. Szeroko reprezentowany w tym zakresie jest pogląd stanowiący swoisty kompromis wypracowany na kanwie sporu powstałego w 2007 r., dotyczącego charakteru kompetencji Prezydenta w zakresie powoływania sędziów ${ }^{32}$. W świetle tego kompromisowego stanowiska Prezydent uprawniony jest do nieuwzględnienia wniosku KRS w sytuacji nadzwyczajnej — może przedstawić swoje zastrzeżenia i jednocześnie zwrócić wniosek Radzie w celu umożliwienia

${ }^{28}$ Właśnie redakcja językowa omawianego przepisu Konstytucji RP stanowi jeden z centralnych argumentów na rzecz w zasadzie odosobnionego stanowiska o prezydenckim związaniu wnioskiem KRS. Vide J. Ciapała, Prezydent $w$ systemie ustrojowym Polski (1989-1997), Warszawa 1999, s. 305. Szerzej na ten temat: P. Kuczma, Kompetencje nominacyjne Prezydenta RP wobec sędziów, „Zeszyty Naukowe Dolnośląskiej Wyższej Szkoły Przedsiębiorczości i Techniki” 2011, nr 4, s. 193-194.

29 Sygn. akt SK 37/08. Szerzej na ten temat vide K. Szczucki, Komentarz do art. 186..., i wskazywana tam literatura.

${ }^{30}$ W. Sokolewicz, Konstytucyjna regulacja władzy sądowniczej, [w:] Konstytucja, ustrój, system finansowy państwa. Księga pamiątkowa ku czci prof. Natalii Gajl, red. T. Dębowska-Romanowska, A. Jankiewicz, Warszawa 1999, s. 174.

31 Szerzej: J. Ciapała, Charakter kompetencji Prezydenta RP..., s. 37.

32 Vide postanowienie Prezydenta RP z 3 stycznia 2008 r., M.P. nr 4, poz. 38. 
reasumpcji uchwały ${ }^{33}$. W literaturze spotkać można także — jak się wydaje mniejszościowy - pogląd o związaniu Prezydenta RP wnioskiem KRS i skorelowanym z nim braku możliwości jego nieuwzględnienia ${ }^{34}$.

\section{Brak rekomendacji KRS}

Poza dyskusją pozostaje fakt, że obowiązujący w Polsce system nominacyjny wyklucza możliwość powołania przez Prezydenta na stanowisko sędziego osoby, która nie uzyskała rekomendacji Rady, a także powołania osoby posiadającej rekomendację na inne stanowisko sędziowskie niż stanowisko objęte wnioskiem $\mathrm{KRS}^{35}$.

Jeśli zaś chodzi o tezę o możliwości nierekomendowania przez KRS żadnego kandydata albo niektórych kandydatów Prezydentowi z uwagi na fakt, że w ocenie Rady nie spełniają oni przesłanek ustawowych, to znajduje ona potwierdzenie w aktach normatywnych oraz w dotychczasowej praktyce funkcjonowania Rady, która została uznana przez Sąd Najwyższy i Trybunał Konstytucyjny. W przytaczanym już uzasadnieniu do postanowienia z 23 czerwca 2008 r. Trybunał podkreślił bowiem, że „niewątpliwie [...] każdy z tych aktów [Rady i Prezydenta — przyp. O.N. i V.V.] poprzedzony jest pewną racjonalizacją [...], która w wypadku Krajowej Rady Sądownictwa uzewnętrznia się $\mathrm{w}$ kolegialnie formułowanej ocenie kandydata na urząd sędziego i finalnie - w treści przedkładanego Prezydentowi wniosku (lub, alternatywnie, w postaci braku takiego wniosku)" ${ }^{36}$.

Stosownie do powyższego w sprawach z odwołań kandydatów, w których KRS nie rekomendowała pozytywnie żadnego z kilku kandydatów, Sąd Najwyższy nie kwestionował tej praktyki ${ }^{37}$. Przykładowo w wyroku z 11 marca 2014 r. Sąd Najwyższy wskazał,

${ }^{33} \mathrm{Z}$ najnowszych wypowiedzi komentatorów na ten temat vide R. Piotrowski, Opinia o zgodności z Konstytucja postanowienia Prezydenta RP odmawiajacego powołania na urząd sędziego mimo wniosku Krajowej Rady Sadownictwa w przedmiocie powołania, Warszawa 2016. Vide także R. Piotrowski, Sędziowie a wtadza wykonawcza. Wybrane problemy konstytucyjne, „Studia Iuridica” 2008, t. 48, s. 211; L. Garlicki, Komentarz do art. 179, [w:] Komentarz do Konstytucji RP, Warszawa 2003. Nieco odmienne stanowisko reprezentują Tadeusz Ereciński, Jacek Gudowski i Józef Iwulski, wskazując, że: „Odmawiając nominacji, zwłaszcza bez uzasadnienia, Prezydent w istocie burzy system powoływania sędziów, a także redukuje ustrojową rolę Krajowej Rady Sądownictwa". Niezależnie od tak stanowczej tezy cytowani autorzy opowiadają się ostatecznie za możliwością przyjęcia wyżej opisanego stanowiska kompromisowego (T. Ereciński, J. Gudowski, J. Iwulski, Komentarz do art. 55..., s. 186-187).

${ }^{34}$ Vide J. Ciapała, Charakter kompetencji Prezydenta RP..., s. 45; J. Gudowski, Urząd sędziego w prawie o ustroju sądów powszechnych, „Przegląd Sądowy” 1994, nr 11/12, s. 26. Confer też P. Tuleja, Konstytucyjne kompetencje Krajowej Rady Sąownictwa, [w:] Trzecia wtadza. Sady i trybunaty w Polsce, red. A. Szmyt, Gdańsk 2008, s. 207; S. Dąbrowski, A. Łazarska, Komentarz do art. 55 p.u.s.p., [w:] Prawo o ustroju sądów powszechnych. Komentarz Lex, red. A. Górski, Warszawa 2013, s. 240-241.

${ }^{35}$ T. Ereciński, J. Gudowski, J. Iwulski, Komentarz do art. 55..., s. 188.

${ }^{36}$ Sygn. akt Kpt $1 / 08$.

${ }^{37}$ Wyrok SN z 11 marca 2014 r., sygn. akt III KRS 3/14; wyrok SN z 6 listopada 2013 r., sygn. akt III KRS 215/13; wyrok SN z 21 lipca 2015 r., sygn. akt III KRS 35/15. 
że „nie ma też racji odwołująca się, zarzucając, że brak przedstawienia Prezydentowi wniosku o powołanie do pełnienia urzędu sędziego stanowi naruszenie kompetencji Rady. Wywodzenie z treści art. 3 ust. 1 pkt 2 ustawy o KRS (który wskazuje, iż do kompetencji Rady należy przedstawienie Prezydentowi Rzeczypospolitej Polskiej wniosków o powołanie sędziów w Sądzie Najwyższym, sądach powszechnych, sądach administracyjnych i sądach wojskowych) wniosku, że Rada jest obowiązana w następstwie każdego przeprowadzanego konkursu przedstawić Prezydentowi kandydaturę któregoś z uczestników postępowania, jest całkowicie chybione. Obowiązkiem Rady jest ocena przydatności kandydatów do pełnienia urzędu na stanowiskach sędziego i na tej podstawie podjęcie stosownej decyzji. W żadnej mierze nie oznacza to, że w efekcie każdego przeprowadzonego konkursu na wolne stanowisko sędziowskie Rada obowiązana jest przedstawić Prezydentowi kandydata $\mathrm{z}$ wnioskiem o powołanie do pełnienia urzędu, jeśli żaden z uczestników postępowania nie spełnia w dostatecznym stopniu stawianych wszystkim kandydatom wymagań" ${ }^{38}$.

Ze wspomnianych wyżej uregulowań prawnych stanowiących podstawę opisywanej praktyki wskazać należy § 17 ust. 6 uchwały nr 1890/2011 KRS z dnia 22 lipca 2011 r. w sprawie regulaminu szczegółowego trybu działania Krajowej Rady Sądownictwa ${ }^{39}$, zgodnie z którym zespół mógł nie rekomendować Radzie żadnego z kandydatów (mógł również rekomendować kandydatów w liczbie mniejszej, równej lub większej od liczby wolnych stanowisk). Ta sama konstrukcja pojawiła się w $\S 18$ ust. 6 uchwały nr 125/2015 KRS z dnia 6 lutego 2015 r. w sprawie regulaminu szczegółowego trybu działania Krajowej Rady Sądownictwa ${ }^{40}$, § 18 ust. 6 uchwały nr 265/2017 KRS z dnia 12 września 2017 r. w sprawie regulaminu szczegółowego trybu działania Krajowej Rady Sądownictwa ${ }^{41}$, a także w aktualnie obowiązującym $\S 19$ ust. 6 uchwały nr 158/2019 KRS z dnia 24 stycznia 2019 r. w sprawie regulaminu szczegółowego trybu działania Krajowej Rady Sądownictwa ${ }^{42}$.

\section{Rekomendowanie kandydatów w liczbie przekraczającej liczbę wolnych stanowisk}

Kwestią niebudzącą kontrowersji, zarówno z punktu widzenia doktryny, jak i praktyki stosowania prawa, a przez to niewymagającą w tym miejscu ani rozwinięcia, ani tym bardziej uzasadnienia, jest możliwość rekomendowania przez KRS kandydatów w liczbie odpowiadającej liczbie miejsc do obsadzenia.

Zagadnieniem szeroko natomiast rozważanym $\mathrm{w}$ doktrynie, jak również podnoszonym w orzecznictwie Sądu Najwyższego pozostaje możliwość objęcia przez KRS

\footnotetext{
${ }^{38}$ Wyrok SN z 11 marca 2014 r., sygn. akt III KRS 3/14... Vide również wyrok SN z 6 listopada 2013 r.

${ }^{39}$ M.P. nr 72, poz. 712.

${ }^{40}$ M.P. poz. 304, ze zm.

${ }^{41}$ M.P. z 2018 r. poz. 840.

${ }^{42}$ M.P. poz. 192.
} 
wnioskiem o powołanie na urząd sędziego większej liczby kandydatów aniżeli liczba wolnych miejsc do obsadzenia. Zauważyć bowiem należy, że ani Konstytucja RP, w szczególności art. 179, ani uregulowania ustawowe nie przesądzają tej kwestii. W literaturze prawa także pojawiają się w tym względzie różne stanowiska. Przykładowo Karol Weitz w komentarzu do art. 179 Konstytucji RP stwierdza: „mając na względzie konstytucyjną pozycję KRS i jej funkcję w procesie nominacyjnym sędziów, obejmującą m.in. kompleksową merytoryczną ocenę kandydatów, przyjąć należy, że — skoro KRS ma występować z wnioskiem o powołanie przez Prezydenta — to objęcie wnioskiem więcej niż jednej osoby co do tego samego stanowiska sędziowskiego, prowadzące do pozostawienia Prezydentowi prawa wyboru tej osoby, którą powoła na stanowisko sędziowskie, kolidowałoby z rolą KRS i intencjami ustrojodawcy. Innymi słowy, w odniesieniu do każdego z obsadzanych stanowisk sędziowskich KRS może w świetle art. 179 sformułować wniosek o powołanie tylko jednej osoby. Nie jest natomiast dopuszczalne objęcie wnioskiem więcej niż jednej osoby co do tego samego stanowiska sędziowskiego, co pozostawiałoby Prezydentowi prawo wyboru tej osoby, którą powoła na stanowisko sędziowskie, które ma zostać obsadzone"43.

Przeciwne stanowisko zajął Krzysztof Szczucki w komentarzu do ustawy o Sądzie Najwyższym, wskazując na możliwość przedstawienia Prezydentowi kandydatów w liczbie większej niż liczba wolnych stanowisk ${ }^{44}$. Na jego poparcie autor przytacza stanowisko Sądu Najwyższego wyrażone w wyroku z 10 czerwca 2009 r., w którym Sąd Najwyższy: ,uznał za potrzebne wyrażenie stanowiska, że w razie równoczesnego zgłoszenia się na wolne stanowisko sędziego kilku (więcej niż jednego) z najlepszych kandydatów do objęcia tego stanowiska - Krajowa Rada Sądownictwa, która nie ma decyzyjnego wpływu na obsadę wolnych stanowisk sędziowskich, bo o mianowaniu sędziów decyduje Prezydent Rzeczypospolitej Polskiej, który zgodnie z art. 179 Konstytucji RP powołuje sędziów na wniosek Krajowej Rady Sądownictwa, nie powinna ograniczać liczby zgłaszanych Prezydentowi RP wniosków o mianowanie na wolne stanowiska sędziowskie do liczby wakujących stanowisk sędziowskich. Skoro KRS jedynie rozpatruje i ocenia kandydatury do pełnienia urzędu sędziowskiego (art. 2 ust. 1 pkt 2 ustawy o KRS) oraz przedstawia Prezydentowi RP wnioski o powołania (nominacje) sędziowskie, to regulacja zawarta w $\S 10$ ust. 2 i 3 rozporządzenia wykonawczego Prezydenta RP z 13 listopada 2007 r., która może przemawiać za ograniczeniem liczby przedstawianych do nominacji wniosków do liczby równej ilości wolnych wakatów sędziowskich, powinna być interpretowana w zgodzie z konstytucyjnym prawem dostępu do służby sędziowskiej na jednakowych zasadach wszystkich najlepszych kandydatur zgłoszonych w takim postępowaniu konkursowym (art. 60 Konstytucji RP). Jeżeli nadto zważyć, że Prezydent RP nie akceptuje wszystkich wniosków KRS o powołanie przedstawionych przez nią kandydatur w liczbie równej ogłoszonym wakatom sędziowskim, to racjonalne i zgodne z prawem będzie przedstawianie Prezydentowi RP

\footnotetext{
${ }^{43}$ K. Weitz, op. cit., s. 1044 i przytaczana tam literatura.

${ }^{44}$ K. Szczucki, Ustawa o Sądzie Najwyższym..., s. 215-216.
} 
przez Krajową Radę Sądownictwa większej liczby (niż liczby wolnych stanowisk sędziowskich) z najlepszych kandydatur do objęcia wolnego urzędu sędziego, a także pozostawienie Prezydentowi RP ostatecznej i suwerennej decyzji o nominacji wybranych kandydatów przez ten konstytucyjny organ decyzyjny. Postulowana zmiana ma istotny walor praktyczny, bo niewątpliwie ograniczy ilość odwołań od uchwał KRS o nieprzedstawieniu wniosków o powołanie do pełnienia urzędu sędziego, którymi kandydaci czują się pokrzywdzeni, gdyż na ogół odczuwają je jako krzywdzące lub «dyskredytujące» ich dotychczasowe osiągnięcia zawodowe"45.

Biorąc pod uwagę opisany wyżej charakter kompetencji Prezydenta określonej w art. 144 ust. 3 pkt 17 Konstytucji RP, za właściwe przyjąć należy drugie z wyżej przedstawionych stanowisk. Jak słusznie bowiem podkreślił Sąd Najwyższy, to Prezydent, w ramach swojej prerogatywy, dokonuje ostatecznego wyboru kandydata i powołuje go na urząd sędziego. Konsekwentnie należy uznać, że Krajowa Rada Sądownictwa, tak dokonując oceny kandydatów, jak i przedstawiając Prezydentowi Rzeczypospolitej Polskiej wniosek o powołanie sędziego, porusza się w przestrzeni wyznaczonej przez trzy konstytucyjne normy: po pierwsze zakodowanego w art. 60 Konstytucji RP prawa równego dostępu do służby publicznej; po drugie zagwarantowanego w art. 45 ust. 1

${ }^{45}$ Sygn. akt III KRS 9/08. Na marginesie odnotować należy, że w wyroku z 14 stycznia 2010 r. Sąd Najwyższy wyraził wątpliwości, co do powyższej interpretacji, nie przedstawiając jednak głębszego ich uzasadnienia: „Odwołujący wprost nawiązuje tu do stanowiska Sądu Najwyższego z wyroku z 10 czerwca 2009 r. (III KRS 9/08), zgodnie z którym w razie równoczesnego zgłoszenia się na wolne stanowisko sędziego kilku (więcej niż jednego) z najlepszych kandydatów do objęcia tego stanowiska - Krajowa Rada Sądownictwa, która nie ma decyzyjnego wpływu na obsadę wolnych stanowisk sędziowskich, bo o mianowaniu sędziów decyduje Prezydent Rzeczypospolitej Polskiej, który zgodnie z art. 179 Konstytucji powołuje sędziów na wniosek Krajowej Rady Sądownictwa, nie powinna ograniczać liczby zgłaszanych Prezydentowi RP wniosków o mianowanie na wolne stanowiska sędziowskie do liczby wakujących do obsadzania stanowisk sędziowskich. Racjonalne i zgodne z prawem będzie przedstawianie Prezydentowi RP przez KRS większej liczby (niż równej liczbie wolnych stanowisk sędziowskich) najlepszych kandydatur do objęcia wolnego urzędu sędziego, a także pozostawienie Prezydentowi RP ostatecznej i suwerennej decyzji o nominacji wybranych kandydatów. Postulowana zmiana ma istotny walor praktyczny, bo niewątpliwie ograniczy ilość odwołań od uchwał KRS o nieprzedstawieniu wniosków o powołanie do pełnienia urzędu sędziego, którymi kandydaci czują się pokrzywdzeni, gdyż na ogół odczuwają je jako krzywdzące lub «dyskredytujące» ich dotychczasowe osiągnięcia zawodowe. Powyższy pogląd (postulowana wykładnia) budzi wątpliwości, a w tej sprawie nie mógł być aprobowany, gdyż w głosowaniu odwołujący się nie uzyskał żadnego poparcia Krajowej Rady Sądownictwa. Konstytucyjny porządek opiera się na zasadzie, iż organy władzy publicznej działają na podstawie i w granicach prawa (art. 7 Konstytucji). Składa się nań pozytywna regulacja prawna, która nie pozwala przyjąć, iżby Prezydent bez pośrednictwa Rady decydował o powołaniu sędziów i stąd Rada winna przedstawiać mu wnioski o powołanie na urząd sędziego wszystkich kandydatów spełniających warunki formalne (minimalne). Sędziowie są powoływani przez Prezydenta Rzeczypospolitej na wniosek Krajowej Rady Sądownictwa (art. 179 Konstytucji). Pozycja Rady określona została bezpośrednio w Konstytucji (art. 186 i 187), co nie pozwala dowolnie redukować jej roli oraz funkcji, zwłaszcza że prócz ustawy to właśnie wskazane już rozporządzenie Prezydenta określa szczegółowo tryb działania i postępowania przed Radą. Uchwały podejmowane są kolegialnie i dalszy ich walor wynika ze składu Rady, gdyż tworzą ją nie tylko sędziowie" (sygn. akt III KRS 26/09). 
Konstytucji RP prawa do sądu; po trzecie zaś wskazanej wyżej konstytucyjnej kompetencji Prezydenta. W sytuacji zatem gdy Rada dojdzie do przekonania, że wynikające z ustawy i istoty określonego urzędu warunki konieczne, a zarazem wystarczające do powołania kandydata na urząd sędziego spełnia większa liczba kandydatów aniżeli liczba stanowisk do obsadzenia, powinna ich wszystkich przedstawić w rekomendacji ${ }^{46}$. Ograniczenie przez Radę liczby rekomendowanych Prezydentowi kandydatur, w przypadku spełnienia przez większą aniżeli liczba miejsc liczbę kandydatów wskazanych wyżej warunków, skutkowałoby naruszeniem wszystkich przywołanych norm konstytucyjnych. Konstytucyjna prerogatywa Prezydenta zostałaby więc w istocie ograniczona do dekretacji decyzji podjętej przez inny organ konstytucyjny, ewentualnie — wobec możliwości niepowołania na urząd zgłoszonego kandydata - odmowy jej realizacji. Wniosek taki stałby w sprzeczności z samą ideą prerogatywy nie tylko Prezydenta, lecz ogólnie prerogatywy jako instytucji prawnej.

Ponadto, jak podkreślił Sąd Najwyższy w wyroku z 26 marca 2019 r. ${ }^{47}$, legitymacja Prezydenta do powoływania na urząd sędziego ma szczególny charakter: „W akcie powołania przez Prezydenta RP na urząd sędziego realizuje się norma stanowiąca podstawową zasadę demokratycznego państwa prawnego, urzeczywistniającego zasady sprawiedliwości społecznej (art. 2 Konstytucji RP), stanowiąca, że władza zwierzchnia w Rzeczypospolitej Polskiej należy do Narodu, który sprawuje władzę przez swoich przedstawicieli lub bezpośrednio (art. 4 Konstytucji RP). Prezydent występuje tu jako głowa państwa (a nie jako organ realizujący część władzy wykonawczej), której legitymacja demokratyczna jest niewątpliwa i najpełniejsza. Prezydent RP łączy demokratycznie wyrażoną wolę Narodu z kreowaniem władzy sądowniczej. Krajowa Rada Sądownictwa, jako szczególny konstytucyjny organ państwa i jedyny legitymowany do tego, przedstawia Prezydentowi RP kandydatów do powołania na urząd sędziego, ale to Prezydent RP, wykonując prerogatywę (art. 144 ust. 3 pkt 17 Konstytucji RP), ostatecznie decyduje o powołaniu na urząd sędziego (art. 179 ust. 1 Konstytucji RP)".

Zgodzić się w końcu należy ze słusznością przywołanego przez Sąd Najwyższy argumentu ze swoistej prakseologicznej racjonalności — jeżeli bowiem Prezydent, w sytuacji gdy liczba przedstawionych kandydatów nie jest większa aniżeli liczba wolnych stanowisk, ma możliwość niepowołania żadnego z przedstawionych przez KRS kandydatów na urząd sędziego albo powołania kilku z nich, względy racjonalności przemawiają właśnie za uznaniem możliwości przedstawienia przez Radę większej liczby kandydatur i pozostawienie Prezydentowi ostatecznej i suwerennej decyzji o nominacji wybranych kandydatów.

${ }^{46}$ Wniosek ten jednoznacznie koresponduje z treścią przywołanych wyżej przepisów regulaminów szczegółowego trybu działania Krajowej Rady Sądownictwa, dotyczących możliwości rekomendowania przez zespół Radzie większej liczby kandydatów aniżeli liczba stanowisk do obsadzenia.

47 Sygn. akt I NO 57/18. 


\section{Standard metodologiczny ocen dokonywanych przez KRS i jego kontrola}

Wracając do zasadniczej kwestii niniejszego opracowania, podkreślić raz jeszcze należy znaczenie standardów metodologicznych oceny kandydatów do pełnienia urzędu sędziego, które przekładają się bezpośrednio na walor eksplanacyjny uzasadnienia do uchwały KRS w tym zakresie. Oprócz prawidłowego doboru kandydatów pod kątem zawodowym na podstawie całokształtu ich kompetencji jednym z głównych zadań nałożonych na KRS jest bowiem zagwarantowanie przejrzystości kryteriów rozstrzygających o zasadności przedstawienia Prezydentowi danego kandydata ${ }^{48}$. Nie ulega wątpliwości, że rzeczone uzasadnienie umożliwiać musi jednoznaczne ustalenie, czy Rada przy ocenie kandydatów wszechstronnie rozważyła wszystkie okoliczności sprawy, stosując przy tym przejrzyste, jednolite i sprawiedliwe kryteria. Chodzi o takie przeprowadzenie procesu decyzyjnego, a następnie jego odzwierciedlenie w uzasadnieniu decyzji (uchwały) KRS, które pozwala jednoznacznie ocenić okoliczności (przesłanki, kryteria), które zadecydowały o udzieleniu rekomendacji kandydatowi na stanowisko sędziowskie.

Pomimo dosyć częstego powoływania się w uchwałach przez KRS na ogólne stwierdzenie, że w procesie oceny kandydatów pod uwagę został wzięty całokształt okoliczności sprawy, a w szczególności oceniane łącznie ich kwalifikacje oraz doświadczenie zawodowe, w wielu przypadkach Rada odstępuje od wyjaśniania, jakie kryteria w istocie zdecydowały o przedstawieniu w uchwale Prezydentowi wniosku o powołanie konkretnego kandydata do pełnienia urzędu sędziego oraz na podstawie jakich kryteriów przyjęła, że inni kandydaci nie wypełniają, ocenianych łącznie, kryteriów wyboru wymienionych w art. 35 ust. 2 pkt 1 i 2 ustawy o KRS. Tym samym pomimo odwołania się przez Radę do ustawowego sformułowania pozostają poważne wątpliwości co do prawidłowości postępowania KRS w związku z procesem oceny kandydatów. Wątpliwości te, trzeba to jednoznacznie podkreślić, nie dotyczą przy tym kompetencji Rady, które przekładają się m.in. na wybór kryteriów oceny, lecz przejrzystego i jednolitego stosowania tych kryteriów.

\section{Kryteria oceny}

Dokonując podziału logicznego kryteriów, którymi kierować się powinna Rada w procesie oceny kandydatów, wyróżnić należy dwie podstawowe grupy:

1) kryteria konstytutywne,

2) kryteria konsekutywne.

Kryteria konstytutywne lub też kryteria sensu stricto $^{49}$ to podstawowe kryteria danego konkursu. Wynikają one bezpośrednio z ustawy lub są istotowo związane ze stanowiskiem, którego dotyczy postępowanie konkursowe.

${ }^{48}$ P. Tuleja, op. cit., s. 206.

${ }^{49}$ Określenia „konstytutywne” i „konsekutywne” zaczerpnęliśmy bezpośrednio z ustaleń metodologicznych odnoszących się do treści nazw. Treść wyróżnionej nazwy to zespół cech, które przysługują każdemu 
Kryteria konsekutywne określić natomiast należy jako cechy konkurencji. Kryteria te, przy spełnieniu przez kilku kandydatów kryteriów konstytutywnych, pozwalają bowiem na ich różnicowanie. Innymi słowy, kryteria konsekutywne, które są istotowo powiązane z kryteriami konstytutywnymi, stanowią kryterium oceny $\mathrm{w}$ ramach danego warunku konstytutywnego. Jest to swoista ocena drugiego stopnia. Kryteria konsekutywne będą mieć szczególne znaczenie w sytuacji, gdy o daną liczbę miejsc ubiegać się będzie większa aniżeli rzeczona liczba kandydatów, przy czym - co oczywiste liczba kandydatów spełniających kryteria konstytutywne przekraczać będzie liczbę stanowisk do obsadzenia. W opisanej sytuacji przedmiotem oceny nie powinno być bowiem tylko spełnienie przez kandydatów kryteriów konstytutywnych, lecz także swoista jakość lub doskonałość ich spełnienia. Oznacza to, że kryteria konsekutywne same w sobie nie muszą stanowić warunków zajmowania określonego stanowiska, lecz służą stworzeniu swoistego rankingu kandydatów, co z kolei — odchodząc od praktyki alfabetycznego porządkowania nazwisk — przełożyć się może na ich kolejność na liście rekomendowanych kandydatów.

\section{Schemat procedury oceny kandydatów do pelnienia urzędu sędziego}
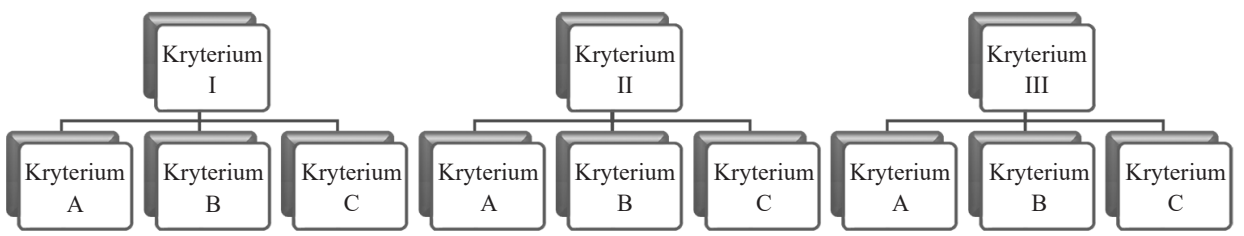

Objaśnienie: ocena pierwszego stopnia obejmuje kryteria konstytutywne, na schemacie oznaczone jako kryteria I, II oraz III. Po pozytywnej weryfikacji kandydatów może nastąpić ocena drugiego stopnia dokonywana $\mathrm{w}$ ramach poszczególnych kryteriów konstytutywnych, obejmująca kryteria konsekutywne oznaczone stosownie jako kryteria A, B i C.

Źródło: opracowanie własne.

Wyróżnienie scharakteryzowanych powyżej grup kryteriów porządkuje sposób oceny kandydatów oraz ostatecznie tworzenia ich listy. Jeśli bowiem od określonej okoliczności uzależniona jest możliwość zajmowania danego stanowiska, to stanowi ona kryterium konstytutywne, oczywiście podlegające ocenie, lecz z góry znane uczestnikowi postępowania. O zastosowaniu kryteriów konsekutywnych decydują natomiast

z jej desygnatów. Na jej podstawie można więc orzec, które przedmioty są desygnatami wyróżnionej nazwy, a które nie są. Cechy konstytutywne, nazywane także cechami istotnymi, to cechy obiektywnie najistotniejsze, stanowiące przy tym swoiste minimum - usunięcie którejkolwiek z nich powodowałoby zmianę denotacji nazwy, czyli wykluczenie z zakresu wyróżnionej nazwy części jej desygnatów. Cechy konsekutywne to natomiast cechy, których usunięcie nie prowadzi do zmiany zakresu nazwy. Jak podkreśla Kazimierz Ajdukiewicz, cechy konsekutywne wynikają z cech konstytutywnych. K. Ajdukiewicz, op. cit., s. 50-51. Vide również S. Lewandowski, H. Machińska, A. Malinowski, J. Petzel, Logika dla prawników, Warszawa 2002, s. 44-45; O. Nawrot, op. cit., s. 63-65; Z. Ziembiński, op. cit., s. 30. 
okoliczności konkretnego postępowania konkursowego. Przykładowo w ramach kryterium konstytutywnego, jakie stanowi doświadczenie w stosowaniu przepisów prawa, Rada może dokonać różnicowania kandydatów z uwagi na różne kryteria konsekutywne, którymi mogą być: dotychczasowy okres zatrudnienia, liczba oraz rodzaj rozpoznanych spraw, ich stopień złożoności itd. Analogicznie, uwzględniając dorobek naukowy, Rada może dokonać różnicowania kandydatów z uwagi na liczbę publikacji naukowych, rodzaje publikacji naukowych, wartość naukową mierzoną np. liczbą uzyskanych punktów ustaloną na podstawie listy czasopism punktowanych $\mathrm{MNiSW}^{50} \mathrm{itp}$.

Podkreślić raz jeszcze należy, że dokonując oceny poprawności zastosowania kryteriów, Sąd Najwyższy nie może ingerować merytorycznie w kompetencje Rady, a tym samym - co do zasady — podważać zasadności odwołania się do wybranego przez Radę kryterium (chyba że kryterium zostało zastosowane niezgodnie z prawem). Sąd Najwyższy może i powinien badać jednak jednolitość branych pod uwagę kryteriów w odniesieniu do różnych kandydatów. Uwaga ta odnosi się w szczególności do zastosowanych przez Radę kryteriów konsekutywnych. Wracając do przykładu z kryterium konstytutywnym, jakie stanowi doświadczenie w stosowaniu przepisów prawa, za błędną z metodologicznego punktu widzenia praktykę należy uznać przeprowadzenie oceny poszczególnych kandydatów na podstawie odmiennych kryteriów konsekutywnych, np. odniesienie do jednego z nich kryterium liczby rozpoznanych spraw, do innego zaś stopnia ich skomplikowania. Rada powinna więc konsekwentnie stosować w ramach określonego kryterium konstytutywnego te same kryteria konsekutywne w odniesieniu do wszystkich kandydatów (naturalnie, w ramach danego kryterium konstytutywnego może uwzględnić kilka kryteriów konsekutywnych).

Stosownie do powyższego uzasadnienie oceny kwalifikacji powinno zostać sporządzone w ten sposób, aby uczestnik postępowania nie miał wątpliwości, z którym kryterium konstytutywnym połączone jest różnicujące jego pozycję kryterium konsekutywne, jakie jest jego znaczenie dla procesu oceny, a także w jaki sposób zostało ono zweryfikowane.

\section{Elementy uzasadnienia oceny dokonanej przez KRS}

Przyjęcie powyższego modelu prowadzi do wniosku, że na Krajowej Radzie Sądownictwa w pierwszej kolejności ciąży obowiązek uzasadnienia, dlaczego dany kandydat nie uzyskał rekomendacji, w szczególności, czy nie spełnił kryterium konstytutywnego, czy też powiązanego z nim kryterium konsekutywnego. W ten sposób możliwa stanie się ocena realizacji przez Radę postulatu równego traktowania w ramach kontroli legalności. Niewskazanie bowiem przez Radę rzeczonych kryteriów uniemożliwia Sądowi Najwyższemu ocenę zgodności z prawem uchwały w przypadku jej zaskarżenia, co

${ }^{50}$ Komunikat Ministra Nauki i Szkolnictwa Wyższego z dnia 31 lipca 2019 r. w sprawie wykazu czasopism naukowych i recenzowanych materiałów z konferencji międzynarodowych wraz z przypisaną liczbą punktów. 
w konsekwencji uzasadnia jej uchylenie i przekazanie sprawy do ponownego rozpoznania. Jak bowiem podkreślił Sąd Najwyższy w wyroku z 14 stycznia 2010 r., w tego rodzaju sytuacjach nie istnieje możliwość, w ramach dokonanej przez KRS oceny, zweryfikowania prawidłowości doboru kryteriów oceny kandydata oraz sposobu ich użycia ${ }^{51}$.

Resumując powyższą część wywodu, uzasadnienie uchwały w przedmiocie przedstawienia Prezydentowi RP kandydata na pozostające do obsadzenia stanowisko sędziowskie powinno wyraźnie wskazywać:

1) które z kryteriów konstytutywnych zostały spełnione, a które niespełnione przez kandydata,

2) w jaki sposób Rada dokonała powyższej oceny (zarówno w odniesieniu do warunków spełnionych, jak i niespełnionych).

W przypadku większej liczby kandydatów aniżeli liczba stanowisk do obsadzenia uzasadnienie powinno dodatkowo wskazywaćs2:

3) w jakim stopniu określony warunek konsekutywny został spełniony przez kandydata,

4) w jaki sposób Rada dokonała oceny stopnia spełnienia przez kandydata warunku konsekutywnego,

5) w jaki sposób ocena, o której mowa w pkt 4, przełożyła się na pozycję kandydata na liście.

\section{Spełnienie warunków konstytutywnych a możliwość nierekomendowania kandydata}

W związku z powyższym przedmiotem dyskusji pozostaje zakres swobody Rady w przedmiocie możliwości nierekomendowania Prezydentowi kandydatów spełniających wszystkie warunki konstytutywne. Jak wyżej wspomniano, warunki konstytutywne wynikają bezpośrednio z ustawy lub pozostają w immanentnym związku z istotą stanowiska. Skoro tak jest, to biorąc pod uwagę fakt, że powoływanie na urząd sędziego stanowi wyłączną prerogatywę Prezydenta, można by przyjąć wniosek o istnieniu obowiązku rekomendowania przez Radę wszystkich kandydatów spełniających warunki konstytutywne. Wówczas zróżnicowanie kandydatów z uwagi na różny stopień spełnienia warunków konsekutywnych przekładałoby się na ich umiejscowienie na liście przekazywanej Prezydentowi, nie zaś na brak rekomendacji. Z drugiej strony nie można zapominać, że wniosek Krajowej Rady Sądownictwa w przedmiocie powołania kandydata do pełnienia urzędu sędziego wiąże się z realizacją przez Radę obowiązku stania na straży niezależności sądów i niezawisłości sędziowskiej. Tym samym Rada powinna dbać o rzeczony poziom „doskonałości” kandydatów na urząd sędziego i odstąpić od rekomendowania Prezydentowi kandydatów, którzy — pomimo

\footnotetext{
${ }^{51}$ Sygn. akt III KRS 24/09.

${ }_{52}$ Wyrok SN z dnia 13 grudnia 2016 r., sygn. akt III KRS 33/16; wyrok SN z 2 lipca 2015 r., sygn. akt III KRS 25/15; wyrok SN z 17 sierpnia...
} 
spełnienia warunków konstytutywnych — nie dają w jej ocenie należytych gwarancji właściwej realizacji obowiązków sędziego. Dodatkowo, jak wskazano wyżej, przyjęty przez ustrojodawcę model współdziałania dwóch organów konstytucyjnych w zakresie powoływania kandydatów na urząd sędziego służy zapewnieniu równowagi pomiędzy kompetencjami Prezydenta a zasadą niezależności władzy sądowniczej. Ograniczenie Rady wyłącznie do roli podmiotu weryfikującego spełnienie przez kandydatów kryteriów konstytutywnych mogłoby więc naruszać konstytucyjną zasadę niezależności władzy sądowniczej.

\title{
VI. Podsumowanie
}

Wracając do zaproponowanego wyżej modelu, podkreślić należy, że dokonana zgodnie z nim ocena oraz odzwierciedlające ją uzasadnienie do uchwały wyczerpałyby obowiązki Rady zarówno w zakresie rozważenia wszystkich istotnych okoliczności sprawy, jak i respektowania konstytucyjnych zasad demokratycznego państwa prawnego, równego traktowania i zakazu dyskryminacji oraz zapewnienia jednakowych szans przy ubieganiu się o pełnienie funkcji publicznych. W szczególności olbrzymim walorem zaproponowanego modelu jest klaryfikacja:

1) kryteriów stanowiących podstawę wyboru,

2) znaczenia wskazanych w pkt 1 kryteriów,

3) mechanizmu oceny kandydatów (w szczególności w zakresie, w jakim umożliwia on jednolitą ocenę kandydatów),

4) sposobu oceny stopnia spełnienia przez kandydatów przyjętych przez Radę kryteriów konsekutywnych.

\section{Bibliografia}

\author{
ŹRÓDŁA
}

Konstytucja Rzeczypospolitej Polskiej z dnia 2 kwietnia 1997 r., Dz.U. nr 78, poz. 483, ze zm. Postanowienie Prezydenta RP z 3 stycznia 2008 r., M.P. nr 4, poz. 38.

Postanowienie TK z 3 czerwca 2008 r., sygn. akt Kpt 1/08.

Postanowienie TK z 23 czerwca 2008 r., sygn. akt Kpt 1/08.

Postanowienie TK z 19 czerwca 2012 r., sygn. akt SK 37/08.

Uchwała nr 1890/2011 KRS z dnia 22 lipca 2011 r. w sprawie regulaminu szczegółowego trybu działania Krajowej Rady Sądownictwa, M.P. nr 72, poz. 712.

Uchwała nr 125/2015 KRS z dnia 6 lutego 2015 r. w sprawie regulaminu szczegółowego trybu działania Krajowej Rady Sądownictwa, M.P. poz. 304, ze zm.

Uchwała nr 265/2017 KRS z dnia 12 września 2017 r. w sprawie regulaminu szczegółowego trybu działania Krajowej Rady Sądownictwa, M.P. z 2018 r. poz. 840. 
Uchwała nr 158/2019 KRS z dnia 24 stycznia 2019 r. w sprawie regulaminu szczegółowego trybu działania Krajowej Rady Sądownictwa, M.P. poz. 192.

Uchwała składu siedmiu sędziów Sądu Najwyższego z dnia 21 grudnia 1993 r., sygn. akt III AZP 20/93.

Ustawa z dnia 17 listopada 1964 r. — Kodeks postępowania cywilnego, Dz.U. nr 43, poz. 296, ze zm.

Ustawa z dnia 27 lipca 2001 r. o Krajowej Radzie Sądownictwa, Dz.U. nr 100, poz. 1082.

Ustawa z dnia 12 maja 2011 r. o Krajowej Radzie Sądownictwa, tekst jedn. Dz.U. z 2019 r. poz. 84 , ze zm.

Wyrok NSA z 22 kwietnia 1993 r., sygn. akt II SA 2577/92.

Wyrok NSA z 27 kwietnia 1995 r., sygn. akt II SA 631/95.

Wyrok SN z 10 czerwca 2009 r., sygn. akt III KRS 9/08.

Wyrok SN z 14 stycznia 2010 r., sygn. akt III KRS 24/09.

Wyrok SN z 14 stycznia 2010 r., sygn. akt III KRS 26/09.

Wyrok SN z 17 sierpnia 2010 r., sygn. akt III KRS 10/10.

Wyrok SN z 5 sierpnia 2011 r., sygn. akt III KRS 9/11.

Wyrok SN z 26 kwietnia 2012 r., sygn. akt III KRS 12/12.

Wyrok SN z 12 czerwca 2012 r., sygn. akt III KRS 15/12.

Wyrok SN z 4 lipca 2012 r., sygn. akt III KRS 16/12.

Wyrok SN z 13 listopada 2012 r., sygn. akt III KRS 32/12.

Wyrok SN z 15 stycznia 2013 r., sygn. akt III KRS 33/12.

Wyrok SN z 6 listopada 2013 r., sygn. akt III KRS 215/13.

Wyrok SN z 22 listopada 2013 r., sygn. akt III KRS 226/3.

Wyrok SN z 11 marca 2014 r., sygn. akt III KRS 3/14.

Wyrok SN z 2 lipca 2015 r., sygn. akt III KRS 25/15.

Wyrok SN z 21 lipca 2015 r., sygn. akt III KRS 35/15.

Wyrok SN z 13 grudnia 2016 r., sygn. akt III KRS 33/16.

Wyrok SN z 13 lipca 2017 r., sygn. akt III KRS 17/17.

Wyrok SN z 7 marca 2019 r., sygn. akt I NO 1/19.

Wyrok SN z 26 marca 2019 r., sygn. akt I NO 57/18.

Wyrok SN z 12 czerwca 2019 r., sygn. akt I NO 38/19.

Wyrok TK z 27 maja 2008 r., sygn. akt SK 57/06.

Wyrok TK z 8 maja 2012 r., sygn. akt K 7/10.

Wyrok TK z 5 czerwca 2012 r., sygn. akt K 18/09.

\section{PIŚMIENNICTWO}

Ajdukiewicz K., Logika pragmatyczna, Państwowe Wydawnictwo Naukowe, Warszawa 1975.

Ciapała J., Charakter kompetencji Prezydenta RP. Uwagi w kontekście kompetencji w zakresie powoływania sędziów, „Przegląd Sejmowy” 2008, nr 4.

Ciapała J., Prezydent $w$ systemie ustrojowym Polski (1989-1997), Wydawnictwo Sejmowe, Warszawa 1999.

Dąbrowski S., Łazarska A., Komentarz do art. 55 p.u.s.p., [w:] Prawo o ustroju sądów powszechnych. Komentarz Lex, red. A. Górski, Wolters Kluwer, Warszawa 2013.

Ereciński T., Gudowski J., Iwulski J., Komentarz do art. 55 u.p.u.s.p., [w:] Prawo o ustroju sądów powszechnych, red. J. Gudowski, LexisNexis, Warszawa 2009.

Ereciński T., Gudowski J., Iwulski J., Komentarz do prawa o ustroju sądów powszechnych i ustawy o Krajowej Radzie Sadownictwa, LexisNexis, Warszawa 2002. 
Florczak-Wątor M., Komentarz do art. 60 Konstytucji RP, [w:] Konstytucja RP, t. 1: Komentarz. Art. 1-86, red. M. Safjan, L. Bosek, Wydawnictwo C.H.Beck, Warszawa 2016.

Garlicki L., Komentarz do art. 179, [w:] Konstytucja Rzeczypospolitej Polskiej. Komentarz, t. 4, red. L. Garlicki, Wydawnictwo Sejmowe, Warszawa 2005.

Garlicki L., Komentarz do art. 179, [w:] L. Garlicki, Komentarz do Konstytucji RP, Wydawnictwo Sejmowe, Warszawa 2003.

Glajcar R., Instytucja Prezydenta w Polsce, Czechach i Stowacji w latach 1989-2000, Wydawnictwo Adam Marszałek, Torun 2005.

Gołba F., Piękoś P., Turkowski P., Logika dla prawników. Wykłady. Ćwiczenia. Zadania, Wydawnictwo C.H.Beck, Warszawa 2012.

Gudowski J., Skarga kasacyjna, [w:] System prawa procesowego cywilnego. Środki zaskarżenia, t. 3, cz. 2, red. J. Gudowski, Wolters Kluwer, Warszawa 2013.

Gudowski J., Urząd sędziego w prawie o ustroju sądów powszechnych, „Przegląd Sądowy” 1994, nr 11/12.

Kuczma P., Kompetencje nominacyjne Prezydenta RP wobec sędziów, „Zeszyty Naukowe Dolnośląskiej Wyższej Szkoły Przedsiębiorczości i Techniki” 2011, nr 4.

Lewandowski S., Machińska H., Malinowski A., Petzel J., Logika dla prawników, LexisNexis, Warszawa 2002.

Mała encyklopedia logiki, red. W. Marciszewski, Zakład Narodowy im. Ossolińskich, Wrocław-Warszawa-Kraków-Gdańsk-Lódź 1988.

Manowska M., Komentarz do art. $398^{13}$ k.p.c., [w:] Kodeks postępowania cywilnego. Komentarz, t. 1, red. M. Manowska, Wolters Kluwer, Warszawa 2015.

Masternak-Kubiak M., Komentarz do art. 179 Konstytucji Rzeczypospolitej Polskiej, [w:] Konstytucja Rzeczypospolitej Polskiej. Komentarz, red. M. Haczkowska, LexisNexis, Warszawa 2014, <https://sip.lex.pl/\#/commentary/587599166/396606>, dostęp 28 VIII 2019.

Michalska M., Zakres rozpoznania sprawy przed Sądem Najwyższym w postępowaniu cywilnym, „Państwo i Prawo” 2003, nr 10.

Nawrot O., Wprowadzenie do logiki dla prawników, Wolters Kluwer, Warszawa 2017.

Niezgódka-Medek M., Komentarz do art. 33 ustawy o Krajowej Radzie Sąownictwa, [w:] M. Niezgódka-Medek, R. Pęk, Krajowa Rada Sąownictwa. Komentarz, LEX, Warszawa 2013.

Piotrowski R., Opinia o zgodności z Konstytucja postanowienia Prezydenta RP odmawiajacego powołania na urząd sędziego mimo wniosku Krajowej Rady Sadownictwa w przedmiocie powołania, Warszawa 2016, <www.krs.pl/admin/files/rp2013/ekspertyza\%20powe\% 20sedziow\%20prof.\%20r.\%20piotrowski\%202016.pdf>.

Piotrowski R., Sędziowie a władza wykonawcza. Wybrane problemy konstytucyjne, „Studia Iuridica” 2008 , t. 48 .

Sokolewicz W., Konstytucyjna regulacja władzy sądowniczej, [w:] Konstytucja, ustrój, system finansowy państwa. Księga pamiątkowa ku czci prof. Natalii Gajl, red. T. Dębowska-Romanowska, A. Jankiewicz, Biuro Trybunału Konstytucyjnego, Warszawa 1999.

Szczucki K., Komentarz do art. 186 Konstytucji RP, [w:] Konstytucja RP, t. 2: Komentarz. Art. 87-243, red. M. Safjan, L. Bosek, Wydawnictwo C.H.Beck, Warszawa 2016.

Szczucki K., Ustawa o Sądzie Najwyższym. Komentarz, Wolters Kluwer, Warszawa 2018.

Tuleja P., Konstytucyjne kompetencje Krajowej Rady Sadownictwa, [w:] Trzecia władza. Sady $i$ trybunaty w Polsce, red. A. Szmyt, Wydawnictwo Uniwersytetu Gdańskiego, Gdańsk 2008.

Weitz K., Komentarz do art. 179 Konstytucji RP, [w:] Konstytucja RP, t. 2: Komentarz. Art. 87-243, red. M. Safjan, L. Bosek, Wydawnictwo C.H.Beck, Warszawa 2016.

Ziembiński Z., Logika praktyczna, Wydawnictwo Naukowe PWN, Warszawa 1995. 